\title{
AKTIVITAS INTEGRATED MARKETING COMMUNICATIONS TERHADAP BRAND IMAGE UNTUK INDUSTRI ROKOK KELAS MILD
}

\author{
Mohamad Hadi Prasetyo \\ Sekolah Tinggi Ilmu Ekonomi (STIE) Ekuitas Bandung \\ Email: hadi.p@ekuitas.ac.id
}

\begin{abstract}
The cigarette industry in Indonesia has evolved from a traditional industry to be one of the important manufacturing sectors in terms of value added, employment and government revenue. On the other hand, aside from increasing social welfare, the government also has a moral responsibility particularly for raising public awareness of their health. Draft of Government Regulation regarding tobacco based-product as an addictive substance expressly prohibits the advertising, promotion and sponsorship of products containing tobacco. In the industry of mild class cigarette, the level of competition gets tighter where many cigarette companies conduct their integrated marketing communication activities in creative ways. This research is aimed at determining the effect of Integrated Marketing Communication variables on Brand Image of mild class cigarette companies in Bandung region. This research type is descriptive and verification research. The method used is survey descriptive method i.e collecting data on the research object by taking a sample of the population. Questionnaires are used as the principal means of collecting data. The positive coefficient shows that there is a positive relationship between the integrated marketing communications with brand image. As t count $>$ t table (7.748> 1.965), HO is rejected. Thus, it is found that there is a significant influence of integrated marketing communications on brand image.
\end{abstract}

Keywords: Marketing, IMC, Brand, Image, Cigarette.

\section{PENDAHULUAN}

Industri rokok di Indonesia telah berkembang dari sebuah industri tradisional menjadi salah satu sektor manufaktur yang penting dalam hal nilai tambah, lapangan kerja dan pendapatan pemerintah. Sebagaimana kita ketahui industri rokok di satu sisi menyediakan lapangan kerja yang sangat besar, cukai rokok juga diyakini merupakan salah satu sumber pendapatan negara, di mana keduanya merupakan hal yang sangat diperlukan pemerintah. Akan tetapi di sisi lain pemerintah juga memiliki tanggung jawab moral khususnya dalam meningkatkan kesadaran penduduknya akan kesehatan selain kesejahteraan dari masyarakat itu sendiri. Akibat dari dilema ini, maka campur tangan pemerintah dalam industri rokok sangat tinggi baik dalam ketenagakerjaan, perpajakan atau cukai, kebijakan harga dan investasi, serta promosi maupun pemasarannya. Intervensi pemerintah ini secara langsung maupun tidak telah membatasi ruang gerak perusahaan rokok ketika menyusun strategi dalam memasarkan produknya yang juga berpengaruh terhadap aktivitas promosi iklan rokok. Rancangan Peraturan Pemerintah (RPP) tentang pengamanan produk tembakau sebagai zat adiktif bagi kesehatan secara tegas melarang iklan, promosi, dan sponsor produk mengandung tembakau, seperti rokok. Peraturan Pemerintah yang baru, yaitu PP No. 109/2012 produk tembakau tidak boleh diiklankan di semua jenis media, baik elektronik, cetak, maupun media luar ruang.

Dalam pandangan perusahaan yang membuat suatu merek untuk suatu produk tidak dapat menghindari adanya komunikasi dengan pelanggan. Dengan adanya kegiatan komunikasi pemasaran yang dilakukan perusahaan, diharapkan dapat membantu terwujudnya tujuan perusahaan. Banyak upaya yang dilakukan perusahaan dalam 


\section{Muhamad Hadi Prasetyo}

mengomunikasikan merek mereka agar produknya meraih "Top Brand". Top Brand bisa dijadikan tolok ukur keberhasilan sebuah merek di pasar.Sebuah merek dapat dikatakan "Top" jika merek tersebut memiliki awareness yang tinggi, market share besar serta memiliki tingkat loyalitas konsumen yang juga bisa dikatakan tinggi. Hal tersebut dapat diraih oleh perusahaan dengan berbagai kegiatan pemasaran yang sudah menjadi program dari perusahaan itu sendiri. Hal tersebut berkaitan dengan strategi yang dilakukan perusahaan tersebut.

Dalam industri rokok kelas mild sendiri, tingkat persaingan semakin tinggi. Dimana banyak perusahaan rokok melakukan aktivitas komunikasi pemasaran terpadunya dengan berbagai cara yang kreatif. Perusahaan melakukan kegiatan terebut semata-mata untuk mencapai target penjualan mereka. Ditambah dengan beragam media komunikasi yang ada, tentunya membutuhkan kejelian dalam menyusun strategi komunikasi pemasaran dan sudah pasti membutuhkan biaya yang tidak sedikit. Hal tersebut dikatakan wajar sebab membangun dan mengelola merek menjadi sukses tidaklah mudah. Banyak perusahaan di industri rokok melakukan aktivitas komunikasi pemasarannya dengan berbagai cara. Melakukan kegiatan yang dituntut untuk kreatif tetapi ada batasan dari peraturan pemerintah.Dalam survei Top Brand Indonesia tahun 2011 dalam majalah "Marketing" no. 02/XI/FEBUARI 2011 untuk kategori rokok mild dapat dilihat sebagai berikut:

\begin{tabular}{ccc}
\hline \multicolumn{3}{c}{ Tabel $\mathbf{1}$ Rokok Mild } \\
\hline \multicolumn{3}{c}{$\mathbf{2 0 1 1}$} \\
\hline Merek & TBI & KET \\
\hline Sampoerna A Mild & $50.4 \%$ & TOP \\
\hline Class Mild & $15.0 \%$ & TOP \\
\hline Star Mild & $9.9 \%$ \\
\hline LA Lights & $8.2 \%$ \\
\hline U Mild & $3.6 \%$ \\
\hline X Mild & $1.2 \%$ \\
\hline Sampoerna A Flava & $1.0 \%$ \\
\hline Sumber: Majalah "Marketing" 02/XI/FEBUARI 2011
\end{tabular}

Dengan banyaknya kegiatan komunikasi pemasaran yang dilakukan oleh perusahaan bersangkutan bisa membantu menempatkan produk mereka dalam rangka menguasai pangsa pasar. Kegiatan komunikasi pemasaran yang dilakukan oleh perusahaan dalam industri rokok kelas mild bisa memunculkan image dari masyarakat luas. Perusahaan pasti menginginkan image positif dari akibat kegiatan komunikasi pemasaran mereka. Banyak masyarakat menyadari bahwa kegiatan komunikasi pemasaran sampoerna A Mild bisa dikatakan lebih kreatif dibanding perusahaan lain. Tetapi kalau kita lihat seperti produk Class Mild dan juga produk Star Mild, sepertinya jarang sekali kita melihat kegiatan komunikasi pemasaran mereka. Lain hal dengan yang dilakukan produk LA-Lights. Kampanye promosi yang dilakukan produk LA-Lights tidak sebanding dengan penguasaan pasar yang masih di bawah $10 \%$. Hal tersebut bisa saja memunculkan image dari masyarakat luas bahwa LALights hanya meramaikan pasar rokok kelas mild. Belum lagi kalau kita melihat produkproduk yang dibawah $8 \%$. Top Brand ini dapat dijadikan acuan untuk mengukur kinerja merek dari perusahaan-perusahaan industri rokok yang bermain di kelas mild. Dari hasil survei tersebut perusahaan dapat melihat posisi mereknya di benak pelanggan. Memang untuk menentukan market share bukan hanya dilihat dari kegiatan komunikasi pemasaran yang dilakukan perusahaan. Tetapi, kegiatan komunikasi pemasaran yang dilakukan perusahaan dengan tujuan mengenalkan produk mereka bisa menjadi sebuah daya tarik agar konsumen ingin mengonsumsi produk mereka.

Banyak sekali kegiatan komunikasi pemasaran yang dilakukan oleh perusahaan rokok kelas mild, tetapi mengapa hanya dua perusahaan yang bisa menembus diatas $10 \%$ pangsa pasarnya. Bukankah promosi merupakan alat utama dalam mengenalkan produknya. Ada 
beberapa perusahaan yang sengaja menyentuh dunia hiburan dalam kegiatan komunikasi pemasaran mereka. Ada juga yang mencoba untuk megkritisi kejadian politik di negara ini dan masih banyak sekali kegiatan komunikasi pemasaran yang dilakukan. Seperti halnya menampilkan beberapa quote yang kreatif. Dalam penelitian ini juga kita akan melihat apakah ada pengaruhnya kegiatan komunikasi pemasaran yang dilakukan terhadap citra merek yang berimbas pada penguasaan pangsa pasar mereka.

Dari hal tersebut timbul pertanyaan dari peneliti bagaimanakah pandangan konsumen dari beberapa kegiatan komunikasi pemasaran yang dilakukan perusahaan rokok kelas mild mengarah kepada citra merek dari masing-masing produk. Pandangan konsumen tersebut tertuang dalam survei Top Brand yang mengindikasikan ada di peringkat berapa produk mereka di mata konsumen. Berdasarkan fenomena yang telah diuraikan di atas, maka identifikasi permasalahan yang akan dianalisis terbatas pada bagaimana dan berapa besar pengaruh kegiatan komunikasi pemasaran (Integrated marketing communications) terhadap citra merek (Brand image) perusahaan rokok kelas mild

\section{KERANGKA TEORITIS}

\section{Integrated Marketing Communications}

Perubahan karakteristik dari tingkah laku konsumen (consumer behavior) di mana saat ini konsumen tidak suka untuk "dipaksa" dalam melihat iklan serta tidak efektifnya penggunaan media iklan tradisional atau menciptakan konsep Integrated marketing communications (IMC) atau yang dikenal dengan istilah dalam bahasa Indonesia adalah Komunikasi Pemasaran Terpadu.

Konsep IMC muncul sejak tahun 1980an di mana Theodore Levitt (1982) dalam bukunya Innovation in Marketing memperkenalkan kata koordinasi dan integrasi di dalam beragam kegiatan promosi. Perusahaan melihat bahwa pentingnya koordinasi dan integrasi dari berbagai elemen promosi dan aktivitas marketing lainnya untuk berkomunikasi dengan para pelanggannya. Tujuan komunikasi harus jelas, apakah untuk keperluan jangka panjang atau untuk keperluan jangka pendek. Tujuan jangka panjang komunikasi yang dilakukan perusahaan ialah membentuk citra dari perusahaan tersebut (Ma'ruf 2006). sedangkan tujuan jangka pendeknya ialah bisa dikatakan untuk menggapai pembeli baru.

Komunikasi adalah proses di mana pemikiran dan pemahaman disampaikan antar individu atau antar individu dengan kelompok (Shimp 2010). Pemasaran merupakan kumpulan kegiatan di mana perusahaan dan organisasi mentransfer nilai antara mereka dan pelanggan (Shimp 2010). Menurut Four As (the American of Advertising Agency) dalam sulaksana (2007), IMC ialah konsep perencanaan komunikasi pemasaran yang mengakui nilai tambah rencana komprehensif yang mengkaji peran strategis masing-masing bentuk komunikasi dan memadukannya untuk meraih kejelasan, konsistensi, dan dampak komunikasi maksimal melalui pengintegrasian pesan. Komunikasi pemasaran terpadu juga merupakan sebuah proses strategi bisnis dalam mengelola hubungan dengan konsumen yang intinya untuk menggerakkan brand value.

Komunikasi pemasaran juga bisa dikatakan suatu proses di mana suatu perusahaan dapat menginformasikan, mempersuasikan, dan mengingatkan konsumen baik secara langsung maupun tidak langsung merek dari produk yang mereka jual. Untuk menyampaikan sesuatu pada konsumen, pemasar kini bisa memilih aktivitas komunikasi tertentu yang sering disebut elemen atau alat yang terdiri dari advertising, sales promotion, event marketing, personal selling, public relation and publicity serta direct. Secara sederhananya IMC dapat diartikan sebagai suatu proses dari pengelolaan Customer relationships yang menggerakkan atau mengomunikasikan brand value (Reid dkk. 2005). Sedangkan secara spesifik, IMC dapat diartikan sebagai proses yang memiliki fungsi bersilang dalam menciptakan dan memelihara 


\section{Muhamad Hadi Prasetyo}

hubungan yang menguntungkan dengan Customer dan stakeholder lainnya dengan mengontrol dan mempengaruhi secara strategis semua pesan yang terkirim kepada kelompok ini serta menggerakkan dialog dengan maksud tertentu kepada mereka.

Seperti juga yang disebutkan oleh Rehman dan Ibrahim (2011), komunikasi pemasaran terpadu dapat membantu perusahaan mempromosikan bisnis dan produk mereka kepada pasar sasaran perusahaan tersebut. Komunikasi pemasaran juga bisa dikatakan suatu proses di mana suatu perusahaan dapat menginformasikan, mempersuasikan, dan mengingatkan konsumen baik secara langsung maupun tidak langsung merek dari produk yang mereka jual. Untuk menyampaikan sesuatu pada konsumen, pemasar kini bisa memilih aktivitas komunikasi tertentu yang sering disebut elemen atau alat yang terdiri dari advertising, sales promotion, event marketing, personal selling, public relation and publicity serta direct.

Tujuan yang ingin dicapai IMC adalah untuk mempengaruhi masyarakat dengan elemen promosinya sampai ke tingkat kognisi, affeksi, dan konasi. Komunikasi pemasaran merupakan "voice" dari perusahaan dan merek mereka, yang berarti memulai membangun hubungan dengan konsumen. (Rehman dan Ibrahim 2011). Langkah-langkah kegiatan komunikasi pemasaran terpadu yang konsisten pada visi selain mampu menentukan arah dalam membangun merek juga menjadi wahana untuk memenangkan persaingan (Harianto 2006). Dalam kaitan dengan industri rokok, Dewhrist and Davis (2005) menyebutkan banyak perusahaan rokok melakukan kegiatan komunikasi pemasarannya dengan ikut mensponsori berbagai acara besar yang menyentuh segmen-segmen tertentu.

\section{Brand Image}

Apabila suatu perusahaan membangun merek dengan mengacu pada konsep merek berbasis pada pelanggan (Customer Based Brand Equity) dan mereka menerima ide tertentu mengenai sifat alami suatu strategi yang dimulai dari kebutuhan dan perilaku konsumen, maka strategi tersebut merupakan sesuatu yang kompetitif dan penuh tantangan dalam membangun sebuah merek. Arslan dan Altuna (2010) menyebutkan brand merupakan hal yang paling penting dan juga bisa menjadi aset terpenting bagi pemilik perusahaan.

Dari hal inilah perusahaan bisa mendapatkan citra dari suatu merek. Citra sebuah merek adalah seperangkat asosiasi unik yang ingin diciptakan atau dipelihara para pemegang merek (Surachman 2008). Asosiasi tersebut yang menyatakan kepada pelanggan apa yang sesungguhnya dijanjikan oleh perusahaan. Namun, perusahaan bisa menginginkan suatu hal tetapi hasilnya tidak selalu sama dengan yang diharapkan. Asosiasi dari suatu merek (citra merek) dapat menentukan pengaruh terhadap keinginan konsumen untuk membeli (Febriani 2008). Menurut Kotler, dkk (2009), citra sebuah merek (brand image) "is the perception and beliefs held by comsumers, as reflected in associations held in comsumer memory".

Citra merek merupakan bagian dari merek itu sendiri yang dapat dikenali namun sulit untuk diungkapkan dengan kata-kata. "Brand image has been conceptualized and operationalized in several ways" (Sondoh et al. 2007). Citra merek yang kuat dapat memberikan sejumlah keunggulan, kapabilitas yang unik yang sulit ditiru, loyalitas pelanggan dan pembelian ulang yang lebih besar, dan masih banyak lagi input positif yang bisa diterima perusahaan (Chandra dalam Faqih 2008). Mengembangkan citra yang kuat membutuhkan kreatifitas dan dan kerja keras. Citra tidak dapat ditanamkan dalam pikiran masyarakat dalam semalam atau disebarkan melalui satu media saja. Sebaliknya citra itu harus disampaikan melalui tiap sarana komunikasi yang tersedia dan disebarkan secara terus-menerus. 
Mempengaruhi citra positif konsumen terhadap merek merupakan suatu hal yang luar biasa karena dengan hal tersebut merek kita bisa bertahan lebih lama karena bisa menjadi sudah menjadi gambar yang positif di pasar. Strategi yang tepat untuk mempengaruhi citra merek konsumen adalah dengan positioning produk. Pemasar mencoba memposisikan mereknya untuk memenuhi kebutuhan segmen sasaran. Dalam memposisikan merek produk pemasar harus lebih dahulu mempunyai konsep produk yang dapat mengomunikasikan manfaat yang diinginkan melalui iklan dan penggunaan media yang akan menjangkau pasar sasaran. Di mana hal tersebut jelas akan terlihat segmentasi dari merek tersebut dan "style" yang menggambarkan bagaimana merek tersebut bekerja di pasar.

Citra merek (Brand image) dapat dianggap sebagai jenis asosiasi yang muncul dibenak konsumen ketika mengingat sebuah merek tertentu. Ada empat faktor penting dari citra merek (Febriani 2008) Recognition; tingkatan atau level dari kesadaran merek. Menggambarkan keberadaan merek dalam pikiran konsumen dan mempengaruhi persepsi serta tingkah laku Reputatuion; status yang dibentuk oleh perusahaan itu sendiri dengan meningkatkan kualitas keseluruhan dari produk tersebut. Affinity; merupakan emotional relationship yang timbul antara sebuah merek dengan konsumennya. Disejajarkan dengan asosiasi positif dan menjadi pijakan konsumen dalam keputusan pembelian serta loyalitas terhadap merek tersebut. Domain; menyangkut seberapa luas jangkauan yang secara potensial didapat suatu merek yang berkaitan dengan scope produk itu sendiri.

\section{METODE PENELITIAN}

Berdasarkan tujuan penelitian, maka jenis penelitian yang digunakan dalam penelitian ini bersifat deskriptif dan verifikatif. Melihat sifat penelitian ini yaitu deskriptif-verifikatif, di mana pengumpulan data dilakukan dilapangan, maka metode penelitian yang digunakan adalah metode deskriptif survey yaitu pengumpulan data yang dilakukan terhadap suatu objek dilapangan dengan mengambil sampel dari suatu populasi dan menggunakan kuesioner sebagai alat pengumpul data yang pokok.Untuk mengetahui pengaruh Integrated Marketing Comunications terhadap Brand Image untuk industri rokok kelas mild, maka diperlukan operasionalisasi variabel. Variabel-variabel yang terlibat dalam penelitian ini yaitu Integrated Marketing Comunications (X) sebagai variabel eksogenus, serta Brand Image (Y) sebagai variabel endogenus. Variabel eksogenus merupakan variabel penyebab atau yang berpengaruh, sedangkan variabel endogenus sebagai variabel akibat atau yang dipengaruhi. Operasionalisasi variabel yang digunakan pada penelitian ini dapat dilihat padatabel dibawah ini.

Tabel 2 Operasionalisasi Variabel

\begin{tabular}{|c|c|c|c|}
\hline Variabel & Indikator & Ukuran & Skala \\
\hline \multirow{6}{*}{$\begin{array}{l}\text { Integrated Marketing } \\
\text { Communicarions }(X)\end{array}$} & Advertising & Tingkat pengenalan iklan & Ordinal \\
\hline & Sales Promotion & $\begin{array}{l}\text { Tingkat komunikasi dan penempatan } \\
\text { alat-alat pemasaran }\end{array}$ & Ordinal \\
\hline & & $\begin{array}{l}\text { Tingkat periode event yang } \\
\text { diselenggarakan, up-to-date }\end{array}$ & \\
\hline & $\begin{array}{l}\text { Event Marketing } \\
\text { and Sponsorship }\end{array}$ & kegiatan, customized yang interaktif & Ordinal \\
\hline & $\begin{array}{l}\text { Public Relation \& } \\
\text { Publicity }\end{array}$ & $\begin{array}{l}\text { Tingkat kredibilitas berita dan } \\
\text { dramatisasi produk }\end{array}$ & Ordinal \\
\hline & Personal Selling & $\begin{array}{l}\text { Tingkat membangun keyakinan, } \\
\text { preferensi, yang mendorong aksi } \\
\text { konsumen }\end{array}$ & Ordinal \\
\hline Brand Image $(Y)$ & Reputation & Tingkat pengenalan merek & Ordinal \\
\hline
\end{tabular}




\begin{tabular}{lllr}
\hline & Tingkat pengakuan merek dalam & Ordinal \\
\cline { 2 - 4 } & Recognition & $\begin{array}{l}\text { Persepsi pelanggan } \\
\text { Tingkat emotional relationship yang } \\
\text { terjadi }\end{array}$ & Ordinal \\
\hline Domain & $\begin{array}{l}\text { Tingkat jangkauan yang secara } \\
\text { potensial didapat suatu merek }\end{array}$ & Ordinal \\
\hline Sumber: data olahan & &
\end{tabular}

Dalam penelitian ini, digunakan kuesioner untuk pengumpulan datanya. Kuesioner dibagi dalam dua bagian, bagian A yaitu untuk pertanyaan yang berkaitan dengan demografi dan bagian B yang memuat pertanyaan-pertanyaan yang berkaitan dengan variabelvariable dalam penelitian ini. Jenis kuesioner yang digunakan dalam penelitian ini adalah kuesioner tertutup dengan menggunakan skala ordinal yang berpedoman pada Likert Summated Rating, yaitu lima alternatif jawaban 1,2,3,4,5 dan setiap nilai yang diperoleh merupakan indikator untuk variabel bebas $(X)$ serta variabel terikat $(Y)$. Dalam penelitian ini, unit analisis penelitian yang digunakan adalah konsumen rokok atau perokok yang berdomisili di kota Bandung dengan umur 18 tahun keatas. Sebenarnya bisa saja dilakukan penelitian dengan sampel bukan hanya konsumen rokok melainkan masyarakat luas, karena aktivitas komunikasi pemasaran lebih besar arahnya ialah mass communications. Namun hal ini kurang meyakinkan peneliti. Jadi, lebih dipilih masyarakat yang perokok tetapi tidak dibatasi oleh merek rokok yang mereka konsumsi. Mengingat banyak sekali peraturan pemerintah tentang rokok, maka peneliti juga mengambil data dari konsumen yang memiliki usia 18 tahun keatas. Dari hal ini peneliti bisa mengambil kesimpulan bahwa banyak konsumen rokok yang memiliki persepsi akan kreativitas yang tinggi terhadap apa yang dilakukan oleh perusahaan terkait dengan kegiatan pemasarannya, khususnya dalam kegiatan komunikasi pemasaran.

Berdasarkan sumbernya, data biasanya dibedakan menjadi dua macam yaitu data primer dan data sekunder. Data primer dalam penelitian ini diperoleh melalui hasil pengumpulan data langsung terhadap sebagian populasi yang diteliti (sampel) dengan menggunakan teknik pengumpulan data tertentu. Sedangkan data sekunder dalam penelitian ini diperoleh dari data yang telah diolah terlebih dahulu oleh orang lain. Time horizon yang digunakan adalah cross sectional, karena pengambilan data dilakukan secara bersamaan dalam kurun waktu tertentu. Selain itu diperlukan analisis kuantitatif, yaitu analisis untuk menguji hipotesis atau mengetahui besarnya pengaruh aktivitas integrated marketing communications terhadap brand image. Analisis Regresi yang digunakan dalam penelitian ini yang merupakan teknik pengujian statistik yang memungkinkan untuk menguji serangkaian hubungan.

HO: $\quad$ Tidak ada pengaruh secara signifikan antara integrated marketing communications dengan brand image.

H1: Ada pengaruh secara signifikan antara integrated marketing communications dengan brand image.

\section{ANALISIS DATA}

Hasil dari survey kuesioner yang disebar didapat beberapa karakteristik responden, dimulai dari jenis kelamin, pekerjaan dan merek rokok kelas mild yang dikonsumsi.Terlihat dalam tabel dibawah ini:

Tabel 3 Karakteristik Responden Berdasarkan Jenis Kelamin

$$
\text { Jenis Kelamin Jumlah Persentase }
$$




\begin{tabular}{ccc}
\hline Pria & 263 & $65,75 \%$ \\
\hline Wanita & 137 & 34,25 \\
\hline Total & 400 & $100 \%$ \\
\hline
\end{tabular}

Sumber: data olahan

Frekuensi dari jenis kelamin responden diketahui bahwa dari 400 responden yang diteliti, 263 orang $(65,75 \%)$ berjenis kelamin pria dan sisanya sebanyak 137 orang $(34,25 \%)$ berjenis kelamin wanita. Hal ini menunjukkan sebagian besar responden adalah pria. Seperti yang kita ketahui juga sebelumnya bahwa kebanyakan perokok berjenis kelamin pria.

\begin{tabular}{|c|c|c|}
\hline Pekerjaan & Jumlah & Persentase \\
\hline Mahasiswa & 139 & $34,75 \%$ \\
\hline Karyawan & 96 & $24 \%$ \\
\hline Wiraswasta & 107 & $26,75 \%$ \\
\hline Profesional & 58 & $14,5 \%$ \\
\hline Total & 400 & $100 \%$ \\
\hline
\end{tabular}

Sumber: data olahan

Frekuensi tentang jenis pekerjaan dari responden diketahui bahwa dari 400 responden yang diteliti, 139 orang $(34,75 \%)$ adalah mahasiswa, 96 orang $(24 \%)$ merupakan karyawan baik swasta maupun pegawai negeri sipil, 107 orang $(26,75 \%)$ berprofesi sebagai wiraswasta dan sisanya sebanyak 58 orang (14,5\%) bekerja sebagai seorang Profesional seperti contohnya guru, dokter, dosen, dll.

\begin{tabular}{|c|c|c|c|}
\hline & $\begin{array}{l}\text { Rokok Kelas Mild } \\
\text { Yang Dikonsumsi }\end{array}$ & Jumlah & Persentase \\
\hline & Sampoerna A Mild & 152 & $38 \%$ \\
\hline & LA-Lights & 86 & $21,5 \%$ \\
\hline & Class Mild & 103 & $25,75 \%$ \\
\hline & StarMild & 59 & $14,75 \%$ \\
\hline & Total & 400 & $100 \%$ \\
\hline
\end{tabular}

Frekuensi dari rokok kelas mild yang dikonsumsi oleh rersponden memperlihatkan bahwa dari 400 responden, paling banyak mengonsumsi rokok kelas mild merek sampoerna A Mild. Dengan data sebanyak 152 responden (38\%), yang mengaku bahwa rokok kelas mild yang mereka konsumsi ialah merek rokok Sampoerna A Mild. Di peringkat kedua terbanyak ialah rokok kelas mild merek Class Mild, yaitu sebanyak 103 responden $(25,75 \%)$. Diikuti oleh merek LA-Lights sebanyak 86 responden (21,5\%). Di paling bawah ialah rokok kelas mild merek StarMild sebanyak 59 responden (14,75\%). 


\section{Muhamad Hadi Prasetyo}

Dari data karakteristik responden diatas, bisa dilihat bahwa responden dalam penelitian ini paling banyak berjenis kelamin pria, dengan pekerjaan sebagai mahasiswa, dan paling banyak mengonsumsi rokok kelas mild merek Sampoerna A Mild. Banyaknya responden berjenis kelamin pria bisa dikatakan merupakan informasi umum yaitu kebanyakan perokok merupakan pria. Rokok kelas mild merek Sampoerna A Mild yang paling banyak dikonsumsi, merupakan refleksi dari data yang didapat bahwa rokok kelas mild merek Sampoerna A Mild menguasai pangsa pasar Indonesia dengan prosentase 50,4\% (lihat tabel 1).

Hasil dari output pengolahan data, didapat :

Tabel 6 Coefficients

\begin{tabular}{|c|c|c|c|c|c|c|}
\hline & \multirow[t]{2}{*}{ Model } & \multicolumn{2}{|c|}{$\begin{array}{c}\text { Unstandardized } \\
\text { Coefficients }\end{array}$} & $\begin{array}{c}\text { Standardized } \\
\text { Coefficients }\end{array}$ & \multirow[t]{2}{*}{$\dagger$} & \multirow[t]{2}{*}{ Sig. } \\
\hline & & B & Std. Error & Beta & & \\
\hline \multirow[t]{2}{*}{1} & (Constant) & 3,330 & 641 & & 5,197 &, 000 \\
\hline & X & , 198 & ,026 & ,362 & 7,748 &, 000 \\
\hline
\end{tabular}

Sumber: data olahan

Persamaan regresi yang didapat $\mathrm{Y}=3,330+0,198 \mathrm{x}$, memperlihatkan bahwa angka konstanta sebesar 3.330 yang artinya jika variabel aktivitas komunikasi pemasaran terpadu $(X)$ perusahaan yang bersangkutan bernilai 0 , maka nilai dari variabel brand image $(Y)$ perusahaan tersebut sebesar 3,330. Koefisien regresi variabel komunikasi pemasaran terpadu (X) sebesar 0,198. Dimana hal tersebut memiliki pengertian jika perusahaan meningkatkan nilai dalam variabel komunikasi pemasaran terpadu (X) sebesar 1 poin, maka nilai variabel brand image (Y) akan mengalami peningkatan sebesar 0,198 poin. Koefisien bernilai positif memiliki arti bahwa terjadi hubungan positif antara integrated marketing communications dengan brand image. Semakin perusahaan meningkatkan aktivitas integrated marketing communications, maka hal tersebut juga meningkatkan nilai dari brand image perusahaan tersebut.

Dari hasil analisis regresi, dapat diketahui nilai † hitung. Dengan menentukan tingkat signifikansi yaitu $a=5 \%$ (signifikansi $5 \%$ atau 0.05 ialah ukuran standar yang sering digunakan dalam penelitian), dilanjut dengan menentukan t hitung yang didapat dari tabel ouput SPSS diperoleh thitung sebesar 7,748. Setelah itu menentukan $\dagger$ tabel. Tabel distribusi $\dagger$ dicari pada $a=5 \%: 2=2,5 \%$ (uji 2 sisi) dengan derajat kebebasan (df) $n-k-1=398$, dimana $n$ merupakan jumlah responden, $k$ merupakan jumlah variabel independen. Dengan pengujian 2 sisi (signifikansi 0,025 ) hasil diperoleh untuk $†$ tabel sebesar 1,965. Kriteria pengujian dalam penelititan ini ialah:

HO diterima jika : † hitung < † tabel

HO ditolak jika : † hitung $>$ † tabel

Dalam penelitian ini didapat nilai $\dagger$ hitung $>\dagger$ tabel $(7,748>1,965)$ maka HO ditolak Karena didapat nilai t hitung > † tabel $(7,748>1,965)$ maka HO ditolak. Maka, hal tersebut memiliki pengertian bahwa ada pengaruh secara signifikan antara integrated marketing communications dengan brand image.

Dapat dilihat juga analisis koefisien korelasi yang untuk mengetahui ada atau tidaknya dan berapakah tingkat hubungan antara integrated marketing communications dengan brand image, dalam tabel sebagai berikut:

Tabel 7 Model Summary 


\begin{tabular}{|c|c|c|c|c|c|c|c|c|c|c|}
\hline \multirow[b]{2}{*}{ Model } & \multirow[b]{2}{*}{$R$} & \multirow[b]{2}{*}{$\begin{array}{c}R \\
\text { Square }\end{array}$} & \multirow[b]{2}{*}{$\begin{array}{l}\text { Adjusted } \\
\text { R Square }\end{array}$} & \multirow{2}{*}{$\begin{array}{l}\text { Std. Error } \\
\text { of the } \\
\text { Estimate }\end{array}$} & \multicolumn{5}{|c|}{ Change Statistics } & \multirow[b]{2}{*}{$\begin{array}{l}\text { Durbin } \\
\text { Watson }\end{array}$} \\
\hline & & & & & $\begin{array}{l}\text { R Square } \\
\text { Change }\end{array}$ & $\begin{array}{c}F \\
\text { Change }\end{array}$ & dfl & df2 & $\begin{array}{c}\text { Sig. F } \\
\text { Change }\end{array}$ & \\
\hline 1 & $362^{a}$ &, 131 &, 129 & 1,49298 &, 131 & 60,036 & 1 & 398 &, 000 & 1,919 \\
\hline
\end{tabular}

b. Dependent Variable: $Y$

Sumber: data olahan

Dari tabel diatas korelasi yang didapat dengan menggunakan metode Least Square/Pearson sebesar $r=0,362$ yang memiliki pengertian korelasi lemah tapi pasti. Dari tabel 7, kita juga dapat melihat koefisien determinasi yaitu $D=r^{2} \times 100 \%$. Didapat hasil koefisien determinasi sebesar $13.1 \%$.

\section{PEMBAHASAN dan KESIMPULAN}

Dari tabel 7 model summary, Dapat dilihat bahwa analisis koefisien korelasi ada atau tidak dan berapakah tingkat hubungan antara integrated marketing communications dengan brand image. Korelasi yang didapat dengan menggunakan metode Least Square/Pearson sebesar $r=0,362$ yang memiliki pengertian korelasi lemah tapi pasti dengan koefisien determinasi yaitu $D=r^{2} \times 100 \%$, yang didapat hasil koefisien determinasi sebesar $13.1 \%$. Dimana hasil tersebut bisa kita katakan bahwa masih banyak variable yang dapat mempengaruhi brand image. Sebanyak $86,9 \%$ (100\% - 13.1\%) yang dimana akan berpengaruh terhadap brand image dari perusahaan tersebut. Maksudnya disini ialah variabel lain selain variabel integrated marketing communications, berpengaruh cukup besar terhadap image perusahaan.

Integrated Marketing Communications merupakan konsep perencanaan komunikasi pemasaran yang mengakui nilai tambah rencana komprehensif yang mengkaji peran strategis masing-masing bentuk komunikasi dan memadukannya untuk meraih kejelasan, konsistensi, dan dampak komunikasi maksimal melalui pengintegrasian pesan. Komunikasi pemasaran terpadu juga merupakan sebuah proses strategi bisnis dalam mengelola hubungan dengan konsumen yang intinya untuk menggerakkan brand value. Kegiatan komunikasi pemasaran memang merupakan salah satu hal yang juga menentukan citra dari produk itu sendiri. Hal tersebut dilakukan berdasarkan bahwa dalam setiap proses komunikasi pemasaran yang dilakukan terdapat informasi tentang karakteristik dari produk itu sendiri. Perusahaan melakukan kegiatan komunikasi pemasaran karena ingin bertujuan mempengaruhi masyarakat sampai ke tingkat kognisi, affeksi, dan konasi dengan elemen promosinya. Karena perusahaan yakin bahwa citra merek dibangun oleh beberapa faktor yang salah satunya ialah kegiatan komunikasi pemasaran.

Dari pengujian hipotesis yang dilakukan dengan metode regresi sederhana dan analisis koefisien korelasi adalah bahwa integrated marketing communications terhadap brand image, memberikan pengaruh sebesar 0,198 poin. Dimana hal tersebut memiiki pengertian bahwa integrated marketing communicationsyang dilakukan perusahaan tidak terlalu besar pengaruhnya terhadap brand image dari perusahaan tersebut. Apabila kita melihat dari sisi analisis koefisien korelasi, didapat hasil korelasi sebesar 0,362 yang berarti bahwa ada hubungan yang lemah tapi pasti antara integrated marketing communications dengan brand image dimana kefisien determinasinya sebesar $13.1 \%$. Dalam pandangan kita untuk beberapa industri selain industri rokok, biasanya aktivitas komunikasi pemasaran yang dilakukan perusahaan bisa mendapatkan persepsi konsumen yang berimbas pada brand image. Dalam hal penelitian ini, dimana melihat industri rokok khususnya perusahaan rokok yang memproduksi rokok kelas mild melakukan aktivitas komunikasi pemasarannya hanya berimbas atau memiliki pangaruh sedikit terhadap brand image. Maksudnya disini ialah dalam industri rokok kelas mild, bukan aktivitas komunikasi pemasaran saja yang mereka lakukan untuk mendapatkan image positif dari konsumen, melainkan juga beberapa hal 


\section{Muhamad Hadi Prasetyo}

yang dinilai bisa meningkatkan image dari konsumen. Beberapa hal tersebut seperti halnya rasa, bentuk, harga, kemasan, dll. Artinya, dalam bisnis ini harus kuat dalam melakukan inovasi produk, bak berupa produk inti maupun hanya inovasi dalam kemasan yang dapat menyentuh heartshare konsumen secara luas.

Perusahaan rokok yang memproduksi rokok kelas mild haruslah bisa membentuk image dari brand mereka bukan hanya melalui aktivitas komunikasi pemasaran saja. Melainkan lebih diperhatikan beberapa faktor seperti hal harga, bentuk, rasa, kemasan, dll, yang dimana semua itu mengarah pada positioning produk pada benak pelanggan. Bisa juga dilakukan inovasi dalam hal aktivitas komunikasi pemasarannya, yang dikarenakan kebanyakan konsumen dalam industri rokok merupakan konsumen yang sudah lama mengenal produk atau perusahaan yang memproduksinya. Maksudnya ialah mencoba lebih mendalami apa yang dilakukan dalam kegiatan komunikasi pemasaran tersebut dan mencoba berinovasi terhadap apa yang dilakukan dirasa akan berdampak positif pada citra merek yang dibangunnya. Mencoba lebih mendalami dan menyisipkan karakteristik produk serta menyebarkan informasi tentang produk termasuk didalamnya juga terdapat performance dari produk itu sendiri. Dari semua itu diharapkan dapat membantu membangun brand image dari perusahaan rokok kelas mild.

\section{IMPLIKASI dan KETERBATASAN}

Bisnis rokok memang sangat terbatas dalam hal apapun, baik berupa iklan di media maupun komunikasi pemasaran secara luas. Alhasil, para marketer yang berkecimpung di bisnis tersebut haruslah lebih kreatif dalam mengenalkan produknya. Karena keterbatasan yang dipengaruhi oleh peraturan itulah yang mengharuskan untuk lebih bermain dalam inovasi apapun untuk megembangkan apa yang sedang dijalankan. Dalam konteks komunikasi pemasaran, menjadi sponsorship merupakan hal yang bisa dikatakan biasa, tetapi inovais dalam penyelenggaraan tersebutlah yang menjadikan luar biasa. Memang pada akhirnya apabila komunikasi pemasaran yang dilakukan perusahaan gagal dalam melakukan kegiatan event marketing dapat berimbas pada image yang terbentuk. Apabila perusahaan sukses dalam melakukan event marketing pun, tetap saja konsumen akan selalu melihat produk pada akhirnya. Disinilah harus tercipta sinergi antara inovasi poduk dengan aktivitas komunikasi pemasaran yang dilakukan. Karena semua itu harus satu pandangan dalam membangun image lewat filosofi sebuah produk. Sebuah perusahaan baik dalam melakukan kegiatan event marketing tetapi tidak berhasil dalam mebuat sebuah produk, bisa dikatakan apa bedanya dengan event organizer yang mungkin hanya bisa mengonsep sebuah acara tetapi produk inti yang harusnya dijual perusahaan tidak mendapat hati di konsumen secara luas.

Keterbatasan dalam penelitian ini ialah sempitnya variabel yang diteliti. Ternyata untuk industri rokok sendiri, aktifitas komunikasi pemasaran juga tidak cukup untuk mendongkrak citra dari sebuah merek yang dimiliki perusahaan. Ada kemungkinan dibutuhkan juga memperhatikan positioning produk. Bisa juga diihat dari aspek produk secara mendalam seperti performance, quality, taste, packaging, dll. Untuk penelitian selanjutnya dapat dikembangkan beberapa variabel lain seperti strategi pemasaran secara keseluruhan, positioning yang dibentuk oleh perusahaan, serta jangkauan distribusi yang dilakukan oleh perusahaan.

\section{DAFTAR REFERENSI}

Adiwijaya, M. danP.S. Djati. 2006. Analisa Strategi Penempatan Merek Sebagai Bagian dalam Komunikasi Pemasaran Terpadu. Jurnal Manajemen. Universitas Kristen Petra. Surabaya. 
Arslan, F.M. andO.K. Altuna. 2010. The Effect of Brand Extensions on Product Brand image. Journal of Product \& Brand Management. 19(3), 170-180. School of Economic and Administrative Sciences, Marmara University, Istanbul. Retrived from Emerald Group Publishing Limited. Turkey.

Dewhirst, T. andB. Davis. 2005.Brand Strategy and Integrated marketing communications (IMC) a case study of player cigarettes brand marketing. The Journal of Advertising vol. 34 No. 4 (winter 2005) pp. 81-92 American Academy of Advertising. Canada.

Faqih. 2008. Pengaruh Strategi Positioning Produk terhadap Citra Merek pada Produk Sunsilk Clean \& Fresh Shampoo. Skripsi pada Fakultas Ekonomi Jurusan Manajemen Universitas Islam Negeri (UIN) Malang: tidak diterbitkan.

Febriani, K. 2008. Program Loyalitas Pelanggan dalam Meningkatkan Citra Merk. Jurnal Bisnis \& Manajemen. 9(1), 39-49.Kadjatmiko, 2002. "Dinamika Sumber Ke vangan bagi Daerah dalam Rangka Otonomi Daerah", Prosiding Workshop Internasional Implementasi Desentralisasi Fiskal sebagai Upaya Memberdayakan Daerah dalam Membiayai Pembangunan Daerah, Fakultas IImu Sosial dan IImu Politik Universitas Katolik Parahyangan, Bandung.

Harianto. 2006. Komunikasi pemasaran terpadu dalam membangun merek: Studi kasus pada komunikasi pemasaran terpadu yang dilakukan RRI dalam membangun merek Radio Publik.Tesis Magister pada FPS Universitas Indonesia: tidak diterbitkan.

Kotler, P. dan K.L. Keller. 2009. Manajemen Pemasaran, (Edisi 13, Jilid 1). Jakarta: Penerbit Erlangga.

Kotler, P. danK.L. Keller. 2009. Manajemen Pemasaran, (Edisi 13, Jilid 2). Jakarta: Penerbit Erlangga.

Kotler, P. dkk. 2009. Marketing Management, An Asian Perspective (5th Ed.) Singapore: Prentice Hall.

Ma'ruf, H. 2006. Pemasaran Ritel. Jakarta: PT. Gramedia Pustaka Utama.

Majalah Marketing. 02/XI/FEBUARI 2011. PT. Dinamika Komunika Marketindo. Jakarta.

Majalah Marketing. 12/X/DESEMBER 2010. PT. Dinamika Komunika Marketindo. Jakarta.

Ramos, V. andS. Franco. 2005. The Impact of Marketing Communications and Price Promotion on Brand Equity. Journal of Brand Management. Retrived from Proquest Publishing Limited.

Rangkuti, F. 2009. Riset Pemasaran, PT Gramedia Pustaka Utama : Jakarta.

Rehman, S. danM.S. Ibrahim. 2011 .Integrated Marketing Communication And Promotion. Journal of Arts, Science \& Commerce E-ISSN 2229-4686 ISSN 2231-4172. International Refereed Research Journal www.researchersworld.com Vol. II, Issue 4,Oct. 2011.

Reid, M. dkk. 2005. The Relationship between Integrated Marketing Communication, Market Orientation, and Brand Orientation. Journal of Advertising, Vol. 34, No. 4, Integrated Marketing Communication (IMC) (Winter, 2005), pp. 11-23 Published by: Taylor \& Francis, Ltd.

Shimp, T.A. 2010. Integrated Marketing Communication, Advertising and Promotion. South Western

Sondoh Jr, S.L. E† al. 2007. The Effect Of Brand image On Overall Satisfaction And Loyalty Intention In The Context Of Color Cosmetic. Asian Academy of Management Journal, Vol. 12, No. 1, 83-107, January 2007. Malaysia.

Sulaksana, U. 2007. Integrated Marketing Communication, Teks dan Kasus. Yogyakarta: Pustaka Pelajar.

Surachman,S. 2008. Dasar-Dasar Manajemen Merek, Alat Pemasaran untuk Memenangkan Persaingan. Malang: Bayumedia Publishing. 